\title{
Evaluasi manajemen program Sekolah Siaga Bencana (SSB)
}

\author{
Rizki Arumning Tyas*, Pujianto Pujianto, Suyanta Suyanta \\ Pascasarjana, Universitas Negeri Yogyakarta. \\ Jl. Colombo No.1, Karang Malang, Depok, Sleman, Daerah Istimewa Yogyakarta 55281, Indonesia. \\ rizkiatyas@gmail.com \\ * Corresponding Author
}

\section{ARTICLE INFO}

\section{Article History}

Received:

16 December 2019;

Revised:

16 June 2020;

Accepted:

19 June 2020

\section{Keywords}

Evaluasi;

Manajemen;

Pelaksanaan;

Perencanaan;

Sekolah Siaga Bencana

(SSB);

Evaluation;

Management;

Implementation;

Planning;

Disaster preparadness

school

\begin{abstract}
Penelitian ini bertujuan untuk mendeskripsikan manajemen sekolah siaga bencana (SSB) di SMP N 2 Cangkringan. Penelitian ini merupakan penelitian kualitatif pendekatan studi kasus. Subjek penelitian adalah kepala sekolah, guru mata pelajaran IPA, guru mata pelajaran IPS, serta kepala tata usaha selaku koordinator pelaksana program SSB. Teknik pengumpulan data menggunakan wawancara, observasi, dan dokumentasi. Analisis data menggunakan model interactive Miles dan Huberman, yang meliputi kondensasi data, penyajian data, dan penarikan kesimpulan. Hasil penelitian menunjukkan bahwa perencanaan program SSB di SMP N 2 Cangkringan diawali dengan penyamaan persepsi dan komitmen antar warga sekolah, dilanjutkan dengan pembuatan rencana kontinjensi bersama warga sekolah dengan komite sekolah dan instansi terkait. Perencanaan diikuti kajian tingkat kesiapsiagaan sekolah serta peningkatan kapasitas dalam bentuk pelatihan untuk semua stakeholder sekolah. Sekolah telah melaksanakan simulasi atau drill pelatihan menghadapi bencana. Namun, belum dilaksanakan evaluasi keterlaksanaan program SSB secara menyeluruh sehingga demi tercapainya tujuan SSB secara maksimal masih diperlukan banyak peningkatan dan dukungan dari berbagai pihak.
\end{abstract}

This research aimed to describe the management of a disaster preparedness programs in SMP N 2 Cangkringan. This research was a qualitative case study approach. The research subjects were the school principal, science subject teacher, social studies teacher, and head of administration as program coordinator. Data collected by interviews, observation, and documentation. Miles and Huberman's model, which included data condensation, data presentation, and conclusion drawing was applied to analyze the data. The results show that the planning of the program began to make an equal perception and commitment among school residents, followed by making contingency plans together with the school community, school committee, and related agencies. Planning is followed by a study of school preparedness levels and capacity building in the form of training for all school stakeholders. The school has carried out a disaster training drill or simulation. However, a comprehensive evaluation of the program has not yet been carried out, so that in order to achieve the program's objectives, many improvements and support from various parties are still needed.

This is an open access article under the $\underline{\mathrm{CC}-\mathrm{BY}-\mathrm{SA}}$ license.

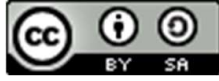

How to cite:

Tyas, R. A., Pujianto, P., \& Suyanta, S. (2020). Evaluasi manajemen program Sekolah Siaga Bencana (SSB). Jurnal Akuntabilitas Manajemen Pendidikan, 8(1), 10-23. doi:https://doi.org/10.21831/jamp.v8i1.28850 


\section{PENDAHULUAN}

Secara geologis, wilayah Indonesia terletak pada pertemuan tiga lempeng litosfer dunia, yaitu lempeng Indo-Australia yang bergerak ke utara, lempeng Eurasia atau Asia Tenggara yang bergerak ke tenggara, dan lempeng Pasifik yang bergerak ke arah barat. Pertemuan tiga lempeng litosfer dunia tersebut terjadi pada wilayah triple junction yang berada di sebelah selatan Papua (Verstappen, 2010). Posisi tersebut menyebabkan Indonesia dilalui oleh dua jalur pegunungan dunia, yaitu Sirkum Mediterania dan Sirkum Pasifik. Wilayah Indonesia terletak di jalur magma, yakni cincin api pasifik atau lingkaran api pasifik yang lebih dikenal dengan sebutan Ring of Fire. Jalur magma ini berbentuk seperti tapal kuda dan mencakup wilayah sepanjang $40.000 \mathrm{~km}$. Daerah ini juga sering disebut sebagai sabuk gempa Pasifik. Oleh karenanya, Indonesia memiliki banyak gunung api. Indonesia dengan 129 Gunung aktif (17\% Gunung di dunia) merupakan salah satu wilayah dengan potensi bencana vulkanik tertinggi di dunia (Verstappen, 2013).

Salah satu gunung api teraktif di Indonesia adalah Gunung Merapi. Gunung Merapi dengan ketinggian 2968 mdpl berada di wilayah Kabupaten Sleman, Kabupaten Magelang, Kabupaten Boyolali, dan Kabupaten Klaten. Gunung Merapi adalah gunung api tipe strato paling giat di Indonesia. Sejak tahun 1672 hingga 2010 tercatat lebih dari 80 kali erupsi, dengan selang waktu istirahat antara 1-18 tahun atau rata-rata 4 tahun. Zona terdampak ancaman bahaya erupsi gunung Merapi di Kabupaten Sleman tersebar di empat wilayah, yakni Kecamatan Ngemplak, Kecamatan Turi, Kecamatan Pakem, dan Kecamatan Cangkringan (Badan Nasional Penanggulangan Bencana, 2011). Berdasarkan data Badan Nasional Penanggulangan Bencana (2011), erupsi gunung Merapi tahun 2010 menimbulkan kerugian dan kerusakan yang sangat parah. Selain banyaknya korban meninggal yang mencapai 353 jiwa dan lebih dari 40.000 pengungsi tersebar di Daerah Istimewa Yogyakarta dan Jawa Tengah, tercatat 2.339 unit rumah di kecamatan Cangkringan dan kecamatan Ngemplak mengalami kerusakan akibat timbunan pasir dan awan panas. Selain kerusakan unit rumah, banyak fasilitas umum seperti pasar, sekolah, serta kantor pemerintahan yang juga mengalami kerusakan.

Indonesia merupakan negara dengan jumlah penduduk terbesar ke-5 di dunia, namun pengetahuan dan tindakan masyarakat Indonesia belum dapat mencerminkan perilaku masyarakat yang memiliki kesiapsiagaan tinggi (Hidayati, 2012). Sebagai negara dengan risiko bencana yang sangat tinggi, Indonesia masih mempunyai banyak masalah berkaitan dengan penanganan bencana. Hal tersebut tercermin pada rendahnya kinerja penanganan bencana, rendahnya perhatian dan fokus terhadap kegiatan mitigasi bencana, serta masih lemahnya peran pendidikan dalam pengenalan mitigasi bencana (Astuti \& Sudaryono, 2010). Sejauh ini, legalisasi penanganan bencana di Indonesia tercermin dalam undang-undang, yaitu Undang-Undang Republik Indonesia Nomor 24 Tahun 2007 tentang Penanggulangan Bencana. Berdasarkan undang-undang tersebut, idealnya, paradigma mitigasi bencana dititikberatkan pada upaya penanggulangan bencana, yakni upaya sebelum terjadi bencana. Namun, anggaran pemerintah untuk kegiatan penanggulangan bencana alam sangat kecil, yaitu $0,699 \%$ dari keseluruhan anggaran nasional. Hal tersebut dimungkinkan karena anggaran belanja pemerintah di negara berkembang dialokasikan untuk evakuasi bencana alam (Kenny, 2012). Seharusnya, apabila kegiatan penanggulangan bencana dilakukan secara maksimal, anggaran tersebut dapat dialihkan ke sektor-sektor lain, seperti kesehatan, pendidikan, maupun pertahanan dan keamanan.

Sebagai objek utama saat terjadi bencana, seharusnya masyarakat mempunyai kecakapan dalam penanggulangan bencana. Masyarakat dapat berperan penuh dalam mewujudkan pengurangan risiko bencana dan penekanan kerugian yang timbul akibat bencana. Apabila masyarakat memiliki perencanaan dan pengetahuan yang baik mengenai hal-hal yang harus dilakukan pada saat sebelum terjadi bencana, pada saat tanggap darurat, serta pada saat pasca bencana, bukan tidak mungkin risiko yang ditimbulkan dari bencana dapat ditekan seminimal mungkin. Pengurangan risiko bencana tentunya diperlukan sinergi dari berbagai pihak, meliputi masyarakat sekitar termasuk didalamnya adalah anak usia dini (Desfandi, 2014). Namun, dalam hal ini, banyak ditemui keterbatasan dan kekurangan pemerintah dalam upaya mitigasi bencana. salah satu solusi yang dapat dilakukan adalah dengan memberi edukasi pada masyarakat luas mengenai upaya-upaya dan tindakan preventif dalam menghadapi bencana. 
Sesuai dengan kerangka Hyogo Framework for Action (HFA) yang diikuti oleh 168 negara dan Indonesia merupakan salah satu negara yang ikut serta, HFA berkomitmen menurunkan hilangnya nyawa, aset sosial, ekonomi, dan lingkungan yang disebabkan karena bencana alam. Salah satu prioritas dari HFA adalah penerapan pendidikan dalam rangka membangun budaya kesiapsiagaan menghadapi bencana pada semua tingkat. Pendidikan merupakan usaha sadar dan terencana untuk mewujudkan suasana belajar dan proses pembelajaran, dengan tujuan agar peserta didik dapat mengembangkan potensi dirinya secara aktif. Pendidikan dapat menjadi sarana yang sangat efektif dalam pengembangan upaya pengurangan risiko bencana, terutama di sekolah-sekolah yang berada di Kawasan Rawan Bencana (KRB). Hal ini mengisyaratkan bahwa sekolah atau institusi pendidikan sangat berperan dalam mendukung program tersebut.

Mendukung hal tersebut, pemerintah mencanangkan program Sekolah Siaga Bencana (SSB) yang bertujuan membangun budaya siap siaga bencana serta membangun ketahanan dalam menghadapi bencana. Konsep SSB tidak hanya terpaku pada unsur kesiapsiagaan, melainkan upaya pengembangan pola pikir dan pengetahuan dalam rangka mewujudkan budaya keselamatan, keamanan, dan ketahanan bagi seluruh warga sekolah. Konsep SSB memiliki dua unsur utama, yakni lingkungan belajar yang aman, serta kesiapsiagaan warga sekolah. SSB diharapkan mampu menjadi sarana optimalisasi penyampaian informasi kebencanaan di tingkat sekolah. Pencanangan program SSB diharapkan menjadi salah satu wujud penanggulangan bencana yang terpadu, terkoordinasi, dan menyeluruh sebagai upaya perlindungan kepada masyarakat akan risiko dan dampak bencana mengingat pengurangan risiko bencana bukan saja menjadi tanggung jawab pemerintah, tetapi tentunya membutuhkan sinergi dari berbagai pihak terutama warga sekolah yang diharapkan mampu mencetak bibit=-bibit penerus generasi bangsa dengan kesadaran dan ketangguhan menghadapi bencana.

Berdasarkan data dari Badan Nasional Penanggulangan Bencana Kabupaten Sleman, tahun 2017 terdapat 38 Sekolah Siaga Bencana (SSB), tahun 2018 terdapat 56 SSB, dan pada tahun 2019 direncanakan akan terdapat 64 SSB. Apabila dibandingkan dengan seluruh sekolah di Kabupaten Sleman yang berjumlah 760 sekolah, apabila dapat terealisasi, pada tahun 2019 ini baru terdapat $8,4 \%$ SSB dari total seluruh sekolah di Kabupaten Sleman. Jumlah tersebut masih sangat kurang apabila mengingat tingginya risiko bencana di Kabupaten Sleman. Salah satu sekolah yang ditunjuk oleh Badan Penanggulangan Bencana Daerah (BPBD) Kabupaten Sleman untuk memberlakukan program SSB adalah SMP Negeri 2 Cangkringan. Tentunya, setiap SSB mempunyai kekhususan yang berbeda, berdasar pada kondisi dan letak geografisnya. SMP Negeri 2 Cangkringan terletak di KRB III Gunung Merapi. Lingkungan SMP Negeri 2 Cangkringan yang terletak pada KRB III rawan bencana Erupsi Gunung Merapi, ditambah dengan banyaknya warga sekolah yang berdomisili di sekitar sekolah, menuntut SMP Negeri 2 Cangkringan beserta seluruh komponen didalamnya untuk senantiasa memiliki sikap siap siaga menghadapi ancaman bahaya yang kapan saja dapat terjadi.

SSB membutuhkan pengelolaan dan manajemen yang baik, agar supaya program tersebut dapat terselenggara dengan maksimal sesuai dengan tujuan yang dicanangkan. Berdasarkan hal tersebut, penelitian mengenai implementasi program SSB dan manajemen pengelolaannya dipandang perlu dilaksanakan, hal tersebut dimaksudkan sebagai evaluasi dan efektifitas pencanangan program SSB, referensi pengembangan SSB bagi sekolah-sekolah lain di kawasan rawan bencana, serta menjadi masukan dan bahan pertimbangan dalam rangka perumusan kebijakan bagi pemerintah sebagai upaya mengembangkan pendidikan bagi masyarakat yang tinggal di kawasan rawan bencana.

\section{METODE}

Penelitian ini merupakan penelitian deskriptif kualitatif dengan pendekatan studi kasus. Penelitian deskriptif merupakan penelitian yang menuturkan pemecahan masalah berdasar data-data untuk dikaji, dianalisis, dan diinterpretasikan. Sementara, penelitian kualitatif dilakukan untuk mengungkap permasalahan yang remang-remang, kompleks, dan dinamis (Sugiyono, 2015). Pendekatan studi kasus merupakan penelitian mengenai suatu kesatuan yang berupa program, kegiatan, peristiwa, atau sekelompok individu yang terkait oleh ikatan tertentu (Fauzan \& Djunaidi, 2012). Hal tersebut dipilih karena penelitian ini menggunakan segala jenis informasi dari fakta-fakta 
yang dideskripsikan ke dalam bentuk narasi. Maksud dan sasaran dari penelitian ini adalah untuk menghimpun dan menggali data secara mendalam, sehingga memperoleh informasi dari kasus keadaan yang terjadi di lapangan berkaitan dengan manajemen program Sekolah Siaga Bencana. Fokus penelitian adalah pada aspek manajemen program SSB yang meliputi perencanaan, pelaksanaan, dan evaluasi program. Penelitian dilaksanakan di SMP Negeri 2 Cangkringan yang beralamat di dusun Pagerjurang, Kepuharjo, Cangkringan. Penentuan sumber data penelitian menggunakan purposive random sampling yang merupakan teknik pengambilan sampel sumber data dengan pertimbangan tertentu sesuai dengan tujuan yang dikehendaki. Adapun sumber data penelitian ini adalah Kepala SMP Negeri 2 Cangkringan, Guru mata pelajaran IPA, Guru mata pelajaran IPS, serta Kepala Tata Usaha selaku koordinator pelaksana program SSB.

Pengumpulan data pada penelitian ini dilakukan dengan wawancara, observasi, dan dokumentasi. Wawancara merupakan salah satu cara pengumpulan data yang dilakukan dengan bertemunya dua orang yang merupakan peneliti dan narasumber untuk kemudian bertukar pikiran dan informasi melalui tanya jawab. Adapun instrumen penelitian yang digunakan dalam wawancara adalah pedoman wawancara. Pedoman wawancara merupakan acuan dalam pelaksanaan wawancara yang sifatnya fleksible dan dapat disesuaikan dengan kondisi lapangan, sehingga bersifat terbuka dan memungkinkan untuk mendapatkan informasi yang lebih mendalam. Herdiansyah (2011) menyatakan bahwa observasi merupakan kegiatan pengumpulan data dengan tujuan menambah penguatan penarikan kesimpulan atau diagnosis. Instrumen penelitian yang digunakan dalam observasi adalah pedoman observasi. Metode dokumentasi menurut Arikunto (2006) merupakan kegiatan mencari data berupa catatan, transkrip, buku, surat kabar, majalah, prasasti, notulensi rapat, maupun agenda yang bertujuan untuk menambah referensi data. Instrumen yang digunakan berupa pedoman dokumentasi. Adapun dokumen yang dihimpun adalah dokumen yang berkaitan dengan manajemen program SSB. Secara garis besar, indikator manajemen SSB di SMP Negeri 2 Cangkringan tercantum pada Tabel 1.

Tabel 1. Indikator Manajemen Sekolah Siaga Bencana

\begin{tabular}{|c|c|c|}
\hline No. & Aspek & Indikator \\
\hline 1 & $\begin{array}{l}\text { Perencanaan Sekolah Siaga } \\
\text { Bencana }\end{array}$ & $\begin{array}{l}\text { Penetapan Tujuan dan Maksud Sekolah Siaga Bencana } \\
\text {. Perencanaan Kurikulum } \\
\text { : Perencanaan Personalia/Tenaga Ahli } \\
\text { I. Perencanaan Sarana dan Prasarana Sekolah Siaga Bencana } \\
\therefore \text { Perencanaan Anggaran Sekolah Siaga Bencana }\end{array}$ \\
\hline 2 & $\begin{array}{l}\text { Pelaksanaan Sekolah Siaga } \\
\text { Bencana }\end{array}$ & $\begin{array}{l}\text { Pengorganisasian Sekolah Siaga Bencana } \\
\text {. Koordinasi Pelaksanaan Program Sekolah Siaga Bencana } \\
\text {. Bentuk Kegiatan Pelaksanaan Program Sekolah Siaga Bencana } \\
\text { l. Keterlibatan Stakeholder } \\
\therefore \text { Pemahaman Masyarakat } \\
\text { Persepsi Siswa Menurut Guru }\end{array}$ \\
\hline 3 & $\begin{array}{l}\text { Evaluasi Program Sekolah Siaga } \\
\text { Bencana }\end{array}$ & $\begin{array}{l}\text { Evaluasi Program Sekolah Siaga Bencana } \\
\text { 1. Hambatan Penyelenggaraan Program Sekolah Siaga Bencana } \\
\text { Upaya Mengatasi Hambatan } \\
\text { l. Ketercapaian Tujuan Sekolah Siaga Bencana }\end{array}$ \\
\hline
\end{tabular}

Analisis data diawali dengan keabsahan data. Kriteria keabsahan data kualitatif menurut Emzir (2012) adalah apabila memiliki derajat kepercayaan (credibility), keteralihan (transferability), ketergantungan (dependability), dan kepastian (confirmability). Dalam penelitian ini, teknik pemeriksaan keabsahan data yang digunakan adalah menggunakan triangulasi sumber dan triangulasi teknik. Tirangulasi adalah teknik pemeriksaan keabsahan data dengan memanfaatkan berbagai sumber maupun teknik, sehingga mendapat banyak data yang bisa dijadikan pertimbangan. Triangulasi sumber berarti bahwa data diperoleh dari sumber yang berbeda-beda dengan teknik yang sama. Adapun triangulasi teknik merupakan penggunaan teknik pengumpulan data yang berbedabeda dari sumber yang sama (Sugiyono, 2012). Setelah proses triangulasi data yang dilakukan terus menerus hingga memperoleh data yang jenuh, langkah selanjutnya adalah analisis data dengan model 
Miles dan Huberman. Analisis data menurut teori Huberman, Miles, dan Saldana (2014) mengikuti tiga langkah, yakni kondensasi data (data condensation), penyajian data (data display), dan penarikan kesimpulan atau verifikasi (drawing and verifying conclusion).

\section{HASIL DAN PEMBAHASAN}

\section{Hasil}

Perencanaan Sekolah Siaga Bencana

Penetapan Tujuan dan Maksud SSB

Hasil penelitian menunjukkan bahwa tujuan dari program SSB adalah memberikan pendidikan kebencanaan bagi seluruh warga sekolah. Penetapan tujuan dan maksud dari program SSB termuat pada dokumen Rencana Kontinjensi Erupsi Gunung Merapi SMP Negeri 2 Cangkringan. Tujuan khusus dari program SSB di SMP Negeri 2 Cangkringan adalah menyelamatkan jiwa warga sekolah, meminimalisir jumlah korban, menghindari dan memperkecil risiko bencana, menekan kerusakan dan kerugian di sekolah akibat bencana, serta memulihkan kegiatan belajar mengajar di sekolah. Dalam dokumen rencana kontinjensi sekolah, tidak tercantum visi dan misi yang berkaitan dengan kebijakan penanggulangan bencana. Begitu pula dalam visi dan misi sekolah, tidak tercantum sub bab yang berkaitan dengan pengurangan risiko bencana. Idealnya, sebagai sekolah yang berlokasi di wilayah KRB III, hal tersebut harus menjadi perhatian dalam penyusunan kelembagaan di sekolah terutama dalam penyusunan kerangka kerja maupun penyusunan visi dan misi sekolah.

Sebagaimana diharapkan, pembangunan dan pengembangan komunitas tangguh bencana merupakan bagian tidak terpisahkan dari produk pendidikan. Tujuan dari hal tersebut adalah menciptakan kesadaran dan perilaku tangguh dalam menghadapi bencana, tentunya dengan dukungan dari lembaga dalam lingkup yang lebih luas. Hal tersebut sudah sesuai dengan maksud dan tujuan dari Roadmap Sekolah atau Madrasah Aman yang dikeluarkan oleh Kementrian Pendidikan dan Kebudayaan, bahwa tujuan dari program SSB adalah untuk menumbuhkembangkan sikap dan kepedulian terhadap risiko bencana, mengembangkan pemahaman tentang risiko bencana meliputi kerentanan sosial, kerentanan fisik, maupun kerentanan perilaku dan motivasi, selain itu juga untuk meningkatkan pengetahuan dan keterampilan dalam rangka pencegahan dan pengurangan risiko bencana. Pada akhirnya, program SSB ini memiliki maksud dalam rangka mengembangkan kesiapan untuk mendukung pembangunan kembali semua elemen yang terkena dampak maupun mengalami kerusakan.

\section{Perencanaan Kurikulum}

Kegiatan perencanaan kurikulum merupakan kegiatan penyusunan Silabus, RPP, maupun dokumen kurikulum lain yang dikaitkan dengan pendidikan kebencanaan. Selain itu, sekolah juga memiliki kewenangan untuk mengembangkan kurikulum yang diintegrasikan dengan muatan lokal sesuai kebutuhan masyarakat lingkungan sekitar. Perencanaan kurikulum di SMP Negeri 2 Cangkringan dilaksanakan oleh guru mata pelajaran yang bersangkutan, bekerjasama dengan forum Musyawarah Guru Mata Pelajaran (MGMP) di Kecamatan Cangkringan. Guru juga memperoleh tambahan referensi mengenai integrasi pembelajaran kebencanaan ke dalam kurikulum dari berbagai lembaga sosial, salah satunya perkumpulan Lingkar, yang disampaikan pada kegiatan sosialisasi SSB. Integrasi pendidikan kebencanaan dengan pembelajaran dilakukan pada mata pelajaran Ilmu Pengetahuan Sosial (IPS). Sudah terdapat silabus dan RPP yang mendukung pendidikan kebencanaan pada mata pelajaran IPS. Materi yang diajarkan dalam pembelajaran meliputi pengenalan ancaman bencana, jenis ancaman, analisis risiko, pembuatan peta risiko, jalur dan rambu evakuasi, serta pelatihan tindakan kesiapsiagaan seperti cara-cara penyelamatan diri dan simulasi bencana.

Implementasi pendidikan kebencanaan di SMP Negeri 2 Cangkringan baru sebatas integrasi dengan mata pelajaran IPS. Belum dilaksanakan integrasi dalam muatan lokal maupun kegiatan ekstrakurikuler. Integrasi dengan mata pelajaran lain juga belum dilaksanakan, seperti halnya pada 
mata pelajaran IPA, KD 3.10 kelas VII atau semester 2 yang seharusnya dapat diiintegrasikan dengan pendidikan kebencanaan, karena spesifikasi KD yang berkaitan dengan struktur bumi dan dinamikanya. Pada KD 4.10 juga tercantum pencapaian KD mengenai pengurangan resiko dan dampak bencana alam serta tindakan penyelamatan diri pada saat terjadi bencana sesuai dengan jenis ancaman bencana di daerahnya.

\section{Perencanaan Personalia / Tenaga Ahli}

Perencanaan personalia/tenaga ahli dalam program SSB di SMP Negeri 2 Cangkringan diprakarsai oleh BPBD DIY yang bekerjasama dengan Kementrian dan Lembaga seperti BPPTK Danramil Kecamatan Cangkringan, dan Kapolsek Kecamatan Cangkringan, pemerintah daerah provinsi Daerah Istimewa Yogyakarta yag meliputi BPBD Provinsi DIY, Dinas Pendidikan Provinsi DIY, Bidang Pencegahan dan Kesiapsiagaan serta Bidang Darurat dan Logistik BPBD DIY, pemerintah Kabupaten Sleman yang meliputi BPBD Kabupaten Sleman, Dinas Pendidikan Kabupaten Sleman, Puskesmas Kecamatan Cangkringan, dan Pemerintah Desa Kepuharjo, serta lembaga-lembaga non pemerintah lainnya seperti Forum PRB DIY, Perkumpulan Lingkar, PMI Kabupaten Sleman, dan NDMC Muhammadiyah Yogyakarta.

\section{Perencanaan Sarana dan Prasarana SSB}

Dalam pelaksanaannya, SMP Negeri 2 Cangkringan melakukan analisis kebutuhan terhadap sarana dan prasarana yang menunjang prorgam SSB bersamaan dnegan penyusunan dokumen rencana kontijensi. Analisis kebutuhan dilakukan oleh masing-masing kelompok tugas (pokgas). Proyeksi kebutuhan sekolah berdasarkan skenario tersebut meliputi alat-alat komando dan komunikasi seperti megaphone, HT, dan lonceng, alat-alat untuk pengamanan aset seperti kardus maupun mobil pick up untuk pengangkutan aset, obat-obatan, minuman, makanan darurat, kebutuhan yang berkaitan dengan kegiatan evakuasi dan penyelamatan seperti drag bar atau tandu, terpal, jas hujan, dan sebagainya. Tidak lupa sekolah juga menyusun kebutuhan yang digunakan dalam kaitannya dengan pelaksanaan pendidikan darurat seperti papan tulis, alat tulis, meja, kursi, dan kertas-kertas serta kebutuhan untuk pendataan siswa.

Berdasarkan hasil observasi, di sekolah juga telah terdapat peta jalur evakuasi, ramburambu, dan prosedur evakuasi yang merupakan bantuan dari BPBD Kabupaten Sleman. Bangunan SMP Negeri 2 Cangkringan juga telah dilengkapi dengan sarana penyelamatan pada keadaan darurat dan telah memenuhi spesifikasi standar sarana prasarana yang ditentukan oleh pemerintah, seperti adanya pintu darurat yang terbuka lebar ke arah halaman (titik evakuasi), terdapat tanda petunjuk arah keluar, mempunyai selasar yang lengkap dengan tanda petunjuk yang mengarahkan ke titik evakuasi, serta dilengkapi dengan berbagai sistem peringatan bahaya dan fasilitas penyelamatan.

\section{Perencanaan Anggaran SSB}

Pada pelaksanaannya, di SMP Negeri 2 Cangkringan, tidak terdapat alokasi anggaran khusus yang memang ditujukan untuk program SSB. Selain tidak ada alokasi anggaran khusus dari sumber dana BOS maupun bantuan dari LSM dan pihak swasta, SMP Negeri 2 Cangkringan juga tidak mendapat alokasi dana langsung dari pemerintah berkaitan dengan program SSB. Selama ini, dalam perwujudannya sekolah memperoleh bantuan secara langsung dari pemerintah dalam bentuk barang dan jasa, karena pihak sekolah juga tidak mengajukan Rencana Anggaran Belanja (RAB) melainkan mengajukan dalam bentuk permintaan barang secara langsung.

Pelaksanaan Sekolah Siaga Bencana

Pengorganisasian SSB

SMP NEGERI 2 Cangkringan menerapkan adanya satuan operasi darurat dalam kaitannya dengan penanggulangan bencana dan pelayanan lainnya. Sistem komunikasi dan koordinasi keadaan darurat terdiri dari penanggungjawab komando tanggap darurat yang dipimpin langsung oleh kepala sekolah dan didampingi oleh wakil komando tanggap darurat. Dibawahnya, terdapat bagian administrasi dan keuangan serta koordinator lapangan yang membawahi beberapa pokgas. Terdapat enam pokgas, yaitu pokgas komunikasi dan peringatan dini, pokgas penyelamatan aset dan sarana 
prasarana, pokgas kesehatan dan konsumsi, pokgas pembelajaran darurat, pokgas evakuasi dan penyelamatan, serta pokgas pendataan siswa. Setiap bagian dan pokgas telah mempunyai deskripsi tugas pokok dan fungsi masing-masing yang juga telah diuraikan dalam tiga tahap, yakni jobdesk pra evakuasi, saat evakuasi, dan pasca evakuasi. Masing-masing pokgas dipimpin oleh satu koordinator yang beranggotakan 3-4 guru.

\section{Koordinasi Pelaksanaan Program SSB}

SMP Negeri 2 Cangkringan juga mempunyai Memorandum of Understanding (MoU) dengan sekolah penyangga yaitu SMP Negeri 1 Cangkringan, yang memuat tentang pelaksanaan pembelajaran darurat apabila terjadi bencana. Kegiatan pembelajaran darurat bagi siswa SMP Negeri 2 Cangkringan dilaksanakan di tiga sekolah penyangga tersebut, sesuai dengan arahan dari BPBD Kabupaten Sleman berkaitan dengan indeks besar kecilnya letusan gunung Merapi. Baik sekolah terdampak maupun sekolah penyangga sama-sama berkomitmen dalam hal pelaksanaan kegiatan pendidikan darurat bagi siswa meski dalam keadaan darurat bencana. Adanya bencana secara tidak langsung akan menyebabkan terbatasnya layanan pembelajaran bagi siswa. Mengacu pada Undang Undang Republik Indonesia Pasal 31 tentang Hak dan Kewajiban Warga Negara, ayat 2 menyatakan bahwa setiap warga negara berhak mendapatkan pendidikan yang layak termasuk di daerah rawan bencana. Dengan adanya kegiatan pendidikan darurat tentunya akan membantu siswa dari sekolah terdampak tetap dapat melaksanakan kegiatan belajar mengajar.

\section{Bentuk Kegiatan Pelaksanaan Program SSB}

Demi mendukung pelaksanaan kebijakan, disusunlah strategi-strategi pencapaian tujuan, seperti pembentukan sistem komando penanganan darurat bencana, pembuatan peraturan yang operasional, pengaktifan tim SSB guru dan siswa sebagai pusat koordinasi dan operasional sekolah, pengoptimalan komunikasi dengan berbagai instansi dan pihak yang terkait, sinkronisasi rencana evakuasi dengan pihak desa dan masyarakat sekitar, serta penyusunan laporan kondisi akhir lapangan dan tanggap darurat yang telah dilakukan. Mendukung hal tersebut, peningkatan kapasitas sekolah yang telah dilaksanakan di SMP Negeri 2 Cangkringan dalam rangka pembentukan dan pengembangan SSB adalah: 1.) Sosialisasi pengurangan risiko bencana bagi sektor pendidikan; 2.) Pengintegrasian materi pengurangan risiko bencana bagi sektor pendidikan; 3.) Penyusunan rencana dan prosedur evakuasi; 4.) Pembuatan dan pemasangan rambu dan prosedur evakuasi; 5.) Penyusunan rencana kontinjensi bencana; 6.) Pelatihan teknis penanggulangan bencana; dan 7.) Gladi lapang dan gladi posko.

1. Sosialisasi pengurangan risiko bencana bagi sektor pendidikan

Mendukung program SSB di SMP Negeri 2 Cangkringan, pihak pihak terkait seperti BPBD

DIY, BPBD Kabupaten Sleman, maupun lembaga-lembaga non pemerintah telah melaksanakan berbagai kegiatan sosialiasasi. Pada tanggal 18 April 2012, BPBD DIY melaksanakan kegiatan sosialiasi SSB di SMP Negeri 2 Cangkringan didukung oleh beberapa lembaga non pemerintah yang turut memberikan materi. Pada kesempatan yang sama, Kepala Bidang Kegawatdaruratan BPBD DIY memberikan materi terkait mitigasi bencana melalui program SSB. Turut serta Kepala Bidang Pencegahan dan Kesiapsiagaan BPBD DIY memberikan materi terkait penanggulangan bencana alam, juga Kepala Bagian Mitigasi Bencana BPBD DIY memberi materi terkait konsep dasar dan aspek-aspek kesiapsiagaan sekolah. Perkumpulan lingkar yang merupakan lembaga nirlaba untuk kerja kemanusiaan dan pengembangan masyarakat juga turut serta memberikan materi berkaitan dengan integrasi pengurangan risiko bencana ke dalam kurikulum pembelajaran. Sasaran dari kegiatan sosialisasi tersebut adalah seluruh komponen sekolah, tidak terkecuali guru, siswa, maupun karyawan sekolah. Namun, sayangnya, kegiatan tersebut hanya dilaksanakan satu kali pada saat perencanaan SSB dan belum dilakukan lagi sampai sekarang.

2. Pengintegrasian materi pengurangan risiko bencana bagi sektor pendidikan

Tingginya kepercayaan masyarakat terhadap budaya lokal dan mitos dibandingkan dengan kepercayaan terhadap pengetahuan ilmiah merupakan keadaan yang kurang menguntungkan bagi pengurangan risiko bencana. Karenanya, diperlukan integrasi antara pengetahuan ilmiah dan 
pengetahuan budaya lokal dalam mengurangi risiko bencana (Cadag \& Gaillard, 2012). Selain itu, guru dan siswa sama-sama memiliki peran yang penting dalam pengurangan risiko bencana, keduanya bertugas memberikan pemahaman yang benar terkait bencana kepada masyarakat luas. Salah satu yang dapat dilakukan oleh guru adalah dengan mengintegrasikan kearifan dan pengetahuan budaya lokal ke dalam mitigasi bencana dan pembelajaran dalam kurikulum 2013 dengan pendekatan saintifik (Suarmika \& Utama, 2017). Upaya menambahkan muatan pengurangan risiko bencana ke dalam kurikulum merupakan sarana potensial. Salah satu yang dapat dilakukan adalah dengan mengintegrasikan ke dalam mata pelajaran IPA dan IPS. SMP Negeri 2 Cangkringan telah megintegrasikan pengurangan risiko bencana dengan pembelajaran IPS di dalam kelas. Tentunya, hal tersebut sangatlah efektif karena dampaknya dapat langsung dirasakan oleh siswa. Sudah terdapat silabus dan RPP yang memuat materi pendidikan kebencanaan. Selain itu, pengurangan risiko bencana dapat diintegrasian pada mata pelajaran IPA yang diwujudkan dengan pembelajaran mengenai mekanisme fenomena alam. Oleh karena bencana alam tidak dapat diprediksi kapan datangnya, fenomena bencana alam dapat diwujudkan dalam bentuk ilustrasi, simulasi, maupun animasi (Selby \& Kagawa, 2012). Namun, di SMP Negeri 2 Cangkringan belum dilaksanakan integrasi pengurangan risiko bencana dengan pembelajaran IPA.

\section{Penyusunan rencana dan prosedur evakuasi}

SMP Negeri 2 Cangkringan menyepakati bahwa rencana kontinjensi bencana erupsi gunung Merapi akan diaktivasi pada level siaga maupun setelah mendapat rekomendasi dari BPBD Kabupaten Sleman maupun dari pemerintah desa Kepuharjo. Rencana dan prosedur evakuasi termuat dalam dokumen rencana kontinjensi sekolah. Rencana dan prosedur evakuasi dimulai dengan peran tim komunikasi dan peringatan dini sekolah dalam hal membangun komunikasi dengan tim pemantau bahaya desa Kepuharjo. Koordinasi dilakukan dengan kepala sekolah guna penyebarluasan peringatan bahaya kepada warga sekolah untuk segera melakukan tindakan penyelamatan diri dengan mengikuti rambu petunjuk dan jalur yang tersedia. SMP Negeri 2 Cangkringan memiliki titik kumpul evakuasi yang telah disepakati, yakni berlokasi di lapangan basket. Dalam keadaan darurat, setelah pokgas komunikasi dan peringatan dini membunyikan sirine khusus sebagai tanda evakuasi, warga sekolah melakukan evakuasi menuju titik kumpul sesuai dengan arahan dan petunjuk teknis yang telah disusun secara detail bagi warga sekolah yang ada di dalam ruang kelas, ruang perpustakaan, maupun luar ruangan. Sekolah juga telah menuliskan petunjuk teknis yang harus dilakukan warga sekolah saat sampai di titik kumpul maupun sesampainya di titik akhir pengungsian. Sekolah juga telah menyusun prosedur tetap pelepasan siswa kembali ke orangtua/wali maupun perangkat desa dan prosedur tetap koordinasi dan pelaporan.

\section{Pembuatan dan pemasangan rambu dan prosedur evakuasi}

SMP Negeri 2 Cangkringan tidak melakukan pembuatan rambu dan prosedur evakuasi karena perlengkapan tersebut diperoleh dari bantun BPBD Kabupaten Sleman. Adapun untuk rambu dan tanda jalur evakuasi terpasang di depan kelas dan ruangan-ruangan yang ada di sekolah, mengarah ke titik kumpul evakuasi. Rambu yang terpasang cukup jelas. Selain dari segi rambu dan prosedur evakuasi, sekolah juga memiliki fasilitas lain seperti alat komunikasi berupa HT, bel peringatan, megaphone, peralatan dapur umum, serta lokasi titik kumpul. Secara keseluruhan SMP Negeri 2 Cangkringan dari segi sarana dan prasarana telah siap untuk menghadapi bencana.

\section{Penyusunan rencana kontinjensi bencana}

SMP Negeri 2 Cangkringan mendapat workshop penyusunan rencana kontinjensi erupsi gunung Merapi oleh BPBD Kabupaten Sleman. Workshop dilaksanakan pada 21 Februari 2013. Dalam kegiatan workshop, sekolah diberi materi terkait tata cara penyusunan dokumen rencana kontinjensi. Sekolah juga diberi materi terkait rencana dan prosedur evakuasi serta kesiapsiagaan darurat bencana di Cangkringan. Penyusunan rencana kontinjensi melibatkan berbagai pihak, seperti BPBD DIY, BPPTK Yogyakarta, BPBD Kabupaten Sleman, serta lembaga non pemerintah lainnya. Dalam kegiatan penyusunan rencana kontinjensi banyak terjadi diskusi antar anggota forum yang berkaitan dengan penetapan kejadian, pengembangan skenario, kebijakan dan strategi, maupun perencanaan sektoral. Dokumen rencana kontinjensi melewati tahap yang panjang sebelum dapat 
dipublikasikan. Draft dokumen rencana kontinjensi terlebih dahulu dipaparkan dan diberi masukan dari berbagai pihak dalam suatu forum sebelum akhirnya forum menyusun rencana pelatihan dan skenario gladi lapang untuk melengkapi kegiatan dalam perwujudan program SSB.

6. Pelatihan teknis penanggulangan bencana

Pelatihan teknis penanggulangan bencana diikuti oleh seluruh warga sekolah. Pelatihan teknis diberikan oleh BPBD DIY pada awal dicanangkannya program SSB di SMP Negeri 2 Cangkringan. Namun, untuk kegiatan sosialiasi pengurangan risiko bencana kepada siswa tetap disampaikan pada saat Masa Orientasi Siswa (MOS) kepada siswa baru maupun pada saat upacara bendera. Kegiatan juga diwujudkan dalam hal pendampingan siswa, pengarahan, pertemuan rutin guru, rapat komite, maupun kegiatan jumat sehat.

7. Gladi lapang dan gladi posko

Gladi Lapang di SMP Negeri 2 Cangkringan ini dirancang untuk mempraktikkan pendekatan end-to-end dalam rangka pengurangan risiko bencana. Kegiatan diawali dengan gladi posko, dilanjutkan dengan gladi bersih, lalu diakhiri dengan gladi lapang. Kegiatan dilaksanakan berdasar skenario yang telah disusun oleh BPBD DIY. Peserta yang terlibat adalah BPPTK sebagai pusat peringatan dini erupsi, pejabat otoritas daerah, Pusdalops, BPBD DIY, dan BPBD Kabupaten Sleman, satuan kerja perangkat daerah termasuk dinas pendidikan dan UPT Dindik di Kecamatan Cangkringan, lembaga-lembaga lain seperti dinas sosial, koramil, polsek, tagana, PMI, SAR, maupun dinas kesehatan, serta warga sekolah. Namun, sayangnya kegiatan gladi lapang dan gladi posko ini hanya dilaksanakan satu kali pada saat awal pencanangan SMP Negeri 2 Cangkringan sebagai SSB. Selebihnya, apabila SMP Negeri 2 Cangkringan tidak mengajukan permohonan kepada instansi terkait, tidak ada kegiatan serupa dilaksanakan. Semestinya, kegiatan serupa dapat dilaksanakan secara berkala maksimal sebanyak satu kali dalam satu tahun berkaitan dengan terus bergantinya siswa yang melakukan kegiatan belajar mengajar di SMP Negeri 2 Cangkringan. Hal ini dimaksudkan untuk memberi pengalaman secara langsung bagi siswa baru sekaligus menyegarkan ingatan siswa lama.

\section{Keterlibatan Stakeholder}

Keterlibatan pemerintah dan instansi lain dalam pelaksanaan program SSB memiliki peranan yang sangat besar. Adanya kerjasama dengan banyak lembaga berkaitan dengan penyelenggaraan pengurangan risiko bencana akan menambah keberhasilan program SSB. Pada pelaksanaannya, SMP Negeri 2 Cangkringan memperoleh dukungan dari pemerintah DIY, pemerintah Kabupaten Sleman, dinas kesehatan/puskesmas, pemerintah kecamatan Cangkringan, desa Kepuharjo, maupun dusun Pagerjurang, serta dari unsur TNI, POLRI, maupun LSM. Dalam hal ini, sekolah terus berupaya untuk aktif menjalin koordinasi dan komunikasi dengan instansiinstansi tersebut. Sekolah mengharapkan adanya dukungan secara langsung dari dinas pendidikan berkaitan dengan integrasi pengurangan risiko bencana ke dalam kurikulum pembelajaran, karena selama ini pemenuhan kebutuhan akan hal tersebut baru tercukupi oleh lembaga non pemerintah yang secara sukarela memberi workshop kepada SMP Negeri 2 Cangkringan.

\section{Pemahaman Masyarakat}

Keterlibatan dan dukungan masyarakat sangat penting dalam peningkatan kemajuan sekolah. Hubungan sekolah dan masyarakat merupakan wadah dalam membina dan mengembangkan pertumbuhan pribadi siswa di sekolah (Mulyasa, 2002). Dukungan masyarakat dusun Pagerjurang pada umumnya dan wali murid pada khususnya yakni sama-sama bersinergi dalam hal menjaga keamanan lingkungan bersama dengan warga sekitar sekolah. Masyarakat sekitar sekolah sudah mengetahui bahwa SMP Negeri 2 Cangkringan merupakan SSB, masyarakat turut mendukung karena dengan adanya program tersebut dapat menambah pengetahuan siswa dan tentunya akan berdampak bagi lingkungan sekitar berkaitan dengan pengurangan risiko bencana.

\section{Persepsi Siswa Menurut Guru}

Pelaksanaan program SSB tidak lepas dari subjek utamanya, yaitu siswa. Siswa diatur oleh tim khusus yang sudah dibentuk oleh sekolah sebagai tim siaga bencana. siswa sangat berperan dalam 
suksesnya program SSB. Hal ini ditunjukkan pada tingginya antusiasme siswa pada saat dilaksanakan kegiatan simulasi maupun gladi lapang. Tanggapan siswa dalam pelaksanaan kegiatankegiatan yang menunjang program SSB juga sangat baik. Siswa dapat mengaplikasikan ilmu yang diperoleh, ditunjukkan dalam sikap tolong menolong antar siswa, sikap saling peduli dan solidaritas yang tinggi apabila ada siswa terkena musibah, perhatian siswa terhadap peringatan dan arahan guru, maupun ketertiban siswa pada saat mengikuti kegiatan-kegiatan di sekolah.

Evaluasi Sekolah Siaga Bencana

\section{Evaluasi Program SSB}

Evaluasi dalam program SSB di SMP Negeri 2 Cangkringan belum dilaksanakan secara maksimal. Evaluasi dilakukan terbatas pada pelaksanaan kegiatan, seperti kegiatan gladi lapang, gladi posko, maupun sosialisasi. Belum dilaksanakan evaluasi kepada seluruh komponen program secara menyeluruh. Pihak-pihak yang telah terlibat dalam kegiatan evaluasi sebatas warga sekolah, seperti guru, siswa, karyawan, dan komite sekolah. Belum dilaksanakan evaluasi dengan melibatkan stakeholder lain dan pihak luar. Idealnya, pelaksanaan evaluasi juga dibersamai dengan kegiatan monitoring dan dilaksanakan oleh seluruh pihak guna semakin memperoleh banyak masukan demi pengembangan program SSB.

\section{Hambatan Penyelenggaraan Program SSB}

Hambatan penyelenggaraan program SSB di SMP Negeri 2 Cangkringan berkaitan dengan anggaran, sarana dan prasarana, kurangnya dukungan dari instansi terkait, dan pengetahuan sumber daya manusia yang masih minim. Sekolah tidak memperoleh dana anggaran khusus untuk penyelenggaraan program SSB. Sekolah juga tidak mungkin memungut dana kepada siswa untuk pelaksanaan program SSB karena status sekolah yang merupakan sekolah negeri. Ketersediaan sarana dan prasarana juga semestinya bisa ditingkatkan lagi meski sarana dan prasarana yang sekarang sudah ada cukup memadahi, namun akan lebih baik apabila jumlah sarana dan prasarana dapat disesuaikan dengan jumlah warga sekolah. Kurangnya perhatian dan dukungan dari instansi terkait juga merupakan hambatan yang cukup berarti. Suksesnya program SSB dapat tercapai apabila mendapat sinergi dari berbagai pihak. Selain berperan dalam kegiatan evaluasi, instansi terkait diharapkan juga dapat melakukan monitoring. Kurangnya pengetahuan sumber daya manusia juga dapat menjadi hambatan. Hal ini berkaitan dengan pengintegrasian materi pengurangan risiko bencana ke dalam kurikulum. Diperlukan dukungan penuh dari dinas pendidikan demi terlaksananya integrasi pembelajaran kebencanaan.

\section{Upaya Mengatasi Hambatan}

Diperlukan keterlibatan semua komponen baik dari warga sekolah maupun instansi dan lembaga yang berfokus pada penanganan bencana untuk memfasilitasi terlaksananya program SSB. Kurangnya rasa peduli semua pihak terhadap pentingnya kesiapsiagaan menghadapi bencana merupakan hambatan terbesar. Kondisi aman dan kondusif dapat menjadi boomerang, karena semua pihak nampak santai dan kurang menjalankan fungsinya. Padahal, bencana tidak dapat diprediksi kapan datangnya.

\section{Ketercapaian Tujuan SSB}

Secara keseluruhan, ketercapaian program SSB di SMP Negeri 2 Cangkringan sudah baik, namun tetap harus dilakukan peningkatan dan perbaikan demi terciptanya program SSB yang semakin bermanfaat bagi seluruh komponen. Diperlukan komitmen untuk pengerahan sumber daya oleh pemangku kepentingan dari berbagai lini pada masa darurat bencana melalui koordinasi yang efektif. Diperukan pembaharuan data secara periodik sesuai karakteristik ancaman untuk kepentingan pembaharuan dokumen rencana kontinjensi dan prosedur tetap peringatan bahaya melalui musyawarah. Selain itu, diperlukan pemantauan secara berkala oleh stakeholder yang berkaitan. Uji coba yang telah dilakukan menghasilkan berbagai temuan yang dapat digunakan sebagai rekomendasi perbaikan dokumen, sehingga semakin sesuai dengan kondisi sekolah. 
Penguatan kapasitas pengetahuan dan keterampilan bagi guru dan siswa di sekolah serta melakukan latihan berkala juga efektif demi mendukung ketercapaian tujuan SSB.

\section{Pembahasan}

SMP Negeri 2 Cangkringan ditunjuk sebagai SSB sejak 10 Juni 2013 setelah memperoleh surat edaran dari Menteri Pendidikan Nasional No. 70a/MPN/SE/2010 pada tanggal 31 Maret 2010 tentang Pengarusutamaan Pengurangan Risiko Bencana di Sekolah. Oleh karena terjadi erupsi besar gunung Merapi pada bulan Oktober-November 2010, realisasi progam SSB di SMP Negeri 2 Cangkringan baru dapat terlaksana pada tahun 2013. Berdasarkan Pasal 51 ayat 2 Perda Provinsi DIY No 8/2010 tentang Penanggulangan Bencana, diketahui bahwa perencanaan kontinjensi dilakukan pada kondisi kesiapsiagaan yang kemudian menghasilkan dokumen rencana kontinjensi (contingency plan), memuat sistem dan mekanisme penanggulangan bencana yang tuntas dan holistik, mulai dari penyusunan kebijakan penanggulangan bencana hingga pembuatan perencanaan teknis penanggulangan bencana. hal tersebut merupakan bagian tak terpisahkan dari program SSB.

Sejalan dengan tujuan untuk melindungi hak-hak siswa maupun tenaga kependidikan dalam kaitannya dengan pengurangan risiko bencana serta untuk memperoleh pendidikan yang berkualitas, aman, dan berkesinambungan, sarana dan prasarana SSB merupakan aspek yang sangat penting disamping anggaran SSB. Hal tersebut relevan dengan Peraturan Pemerintah Nomor 21 Tahun 2008 tentang Penanggulangan Bencana, Pasal 20 menyatakan bahwa terdapat aturan yang berkaitan dengan pengaturan pembangunan, pembangunan infrastruktur, dan tata bangunan yang wajib menerapkan aturan standar teknis bangunan, meliputi adanya sarana dan prasarana yang mendukung.

Aspek yang sangat berperan dalam suksesnya suatu program, termasuk program SSB adalah penganggaran. Keuangan dan pembiayaan merupakan salah satu sumber daya yang secara langsung menunjang efektivitas keberlangsungan pengelolaan pendidikan. Sejalan dengan itu, pemerintah melalui Anggaran Pendapatan dan Belanja Negara (APBN) di lingkungan Kemendikbud telah mengalokasikan anggaran dalam bentuk Dana Alokasi Khusus (DAK) yakni dana yang bersumber dari pendapatan APBN yang dialokasikan kepada daerah tertentu dengan tujuan pendanaan kegiatan khusus yang menjadi urusan daerah namun tetap disesuaikan dengan skala prioritas nasional (Suharwoto, Amri, Pantjastuti, Praptono, \& Wihdiyanto, 2015). DAK digunakan untuk pembangunan sarana prasarana, rehabilitasi sekolah, pembangunan sekolah, pembangunan laboratorium, pembangunan perpustakaan, dan sarana prasarana lainnya dalma kaitan dengan optimalisasi program SSB.

Pengorganisasian SSB di SMP Negeri 2 Cangkringan diawali dari membangun kerjasama dengan BPBD DIY serta BPBD Kabupaten Sleman, Dinas Pendidikan Kabupaten Sleman, pemerintah desa Kepuharjo, BPPTKG, dan beberapa LSM. Kemudian dilaksanakan penyusunan dokumen rencana kontinjensi yang dibimbing langsung oleh BPBD Kabupaten Sleman. Dokumen rencana kontinjensi berisi langkah-langkah dan prosedur kebijakan maupun strategi yang diambil sekolah pada sebelum, saat, dan setelah terjadi bencana. Koordinasi merupakan salah satu rangkaian dalam pelaksanaan program SSB. Koordinasi dilakukan secara langsung oleh Kepala Sekolah selaku pemegang fungsi komando. Pada tahap pra-evakuasi, koordinasi dilakukan dengan beberapa instansi terkait, seperti sekolah penyangga yang meliputi SMP Negeri 1 Cangkringan, SMP Muhammadiyah Ngemplak, dan SMP Negeri 1 Ngemplak. Koordinasi juga dilakukan dengan dinas kesehatan, puskesmas, dan rumah sakit yang dalam hal ini dilakukan dengan PKU Muhammadiyah Pakem dan RS Panti Nugroho. Koordinasi juga dilakukan dengan BPBD Kabupaten Sleman, pemerintah desa Kepuharjo, Kapolsek Kecamatan Cangkringan, Danramil Kecamatan Cangkringan, serta LSM dan pihak-pihak lain yang mendukung. Kegiatan koordinasi ditujukan untuk mengefektifkan kerjasama dengan instansi tersebut di atas serta melaksanakan rencana dan evaluasi penyelesaian masalah apabila terjadi bencana.

Sasaran dari progam SSB di SMP N 2 Cangkringan adalah semua elemen sekolah dapat melakukan tanggap darurat secara cepat dan tepat pada saat terjadi bencana. Tentunya, hal tersebut selaras dengan tujuan program SSB yang berkaitan dengan menghindari adanya korban, memperkecil jumlah kerugian, penyelamatan aset dan dokumen penting sekolah, serta mengurangi kerentanan baik fisik maupun non fisik. Sekolah juga berkomitmen untuk tetap menyelenggarakan pendidikan darurat yang berkelanjutan dan memberikan jaminan terhadap rasa aman baik secara fisik 
maupun mental, serta mendukung trauma healing bagi siswa terdampak bencana. Tahap akhir dari serangkaian penyelenggaraan sebuah program yaitu tahap evaluasi. Evaluasi bertujuan untuk mengetahui seberapa jauh program dilaksanakan. Selain itu, evaluasi bertujuan untuk mengetahui pencapaian program (Arikunto \& Jabar, 2014). Evaluasi sekolah siaga bencana merupakan serangkaian proses penilaian pencapaian tujuan dan pengungkapan masalah kinerja program. Hal tersebut bertujuan untuk memberikan umpan balik sebagai langkah peningkatan kualitas kinerja program (Koswara \& Triyono, 2011).

Lembaga terkait seperti BPBD diharapkan rutin melakukan monitoring terhadap program SSB secara sistematis dan kontinu terkait pengembangan SSB, sehingga semua pihak terbiasa dan terlatih apabila sewaktu-waktu terjadi bencana. Monitoring juga dapat mengetahui ketercapaian dan kekurangan masing-masing parameter kesiapsiagaan. Setidaknya, dengan adanya monitoring akan dapat mengungkap masalah yang mungkin dihadapi, apakah program dan strategi yang dilakukan berjalan sesuai rencana, apakah program menghasilkan output yang direncanakan, dan keterlibatan pihak-pihak terkait dalam pelaksanaan program (Koswara \& Triyono, 2011).

Pelaksanaan pembelajaran yang terintegrasi dengan pengurangan risiko bencana juga bukanlah hal yang mudah. Banyak tantangan dalam pengintegrasian upaya pengurangan risiko bencana ke dalam pembelajaran, seperti beban kurikulum yang tentunya akan bertambah, kurangnya kapasitas guru dalam integrasi pengurangan risiko bencana ke dalam kurikulum, minimnya panduan kebencanaan yang dapat diakses guru serta keterbatasan sumber daya dan sarana prasarana. Namun demikian, pengurangan risiko bencana melalui pendidikan formal harus terus diupayakan (Suharwoto, Amri, Pantjastuti, Praptono, \& Wihdiyanto, 2015). Dengan demikian, diperlukan komitmen dari kepala sekolah dan seluruh warga sekolah serta dukungan dan keterlibatan secara terus menerus dari dinas pendidikan, lembaga, dan organisasi terkait pengurangan risiko bencana demi suksesnya program SSB.

\section{SIMPULAN}

Berdasarkan hasil penelitian dan pembahasan, dapat ditarik kesimpulan bahwa program SSB di SMP Negeri 2 Cangkringan meliputi pembangunan kesepahaman dan komitmen antar warga sekolah, dilanjutkan dengan pembuatan rencana kontinjensi bersama-sama warga sekolah dengan komite sekolah dan instansi terkait. Melakukan kajian tingkat kesiapsiagaan sekolah, tidak lupa diimbangi dengan peningkatan kapasitas dalam bentuk pelatihan untuk semua stakeholder sekolah tidak terkecuali guru, karyawan, dan siswa. Sekolah juga merumuskan kegiatan untuk meningkatkan pengetahuan dan sikap terhadap risiko bencana, rencana tanggap darurat, sistem peringatan dini, dan mobilisasi sumber daya terhadap warga sekolah. Dalam perencanaannya, program SSB SMP Negeri 2 Cangkringan didukung oleh berbagai pihak, seperti pemerintah DIY, jajaran pemerintah Kabupaten Sleman, jajaran pemerintah Kecamatan Cangkringan, jajaran pemerintah Desa Kepuharjo, LSM, serta masyarakat sekitar. SMP Negeri 2 Cangkringan telah melaksanakan kegiatan simulasi atau drill pelatihan menghadapi bencana.

Dengan adanya program SSB dan kegiatan-kegiatan pendukung tersebut, dapat menjadi pedoman dan acuan bagi sekolah dalam melakukan upaya tanggap darurat bencana. Selain itu, menjadi salah satu upaya membangun kesiapsiagaan sekolah dengan pelaksanaan uji materi atau simulasi tanggap darurat bencana yang idealnya dapat dilakukan evaluasi setelah pelaksaan kegiatan secara rutin, minimal setiap tahun sekali. Namun, pada pelaksanaannya program SSB di SMP Negeri 2 Cangkringan mengalami kemacetan, seiring dengan tidak adanya peningkatan aktivitas yang berarti dari erupsi gunung Merapi. SMP Negeri 2 Cangkringan masih terus berupaya meningkatkan komitmen dari berbagai pihak dan pemangku kepentingan di tingkat sekolah maupun desa melalui sistem koordinasi yang efektif, ada atau tidak ada tanda-tanda bahaya. Hal ini dimaksudkan untuk tetap membangun budaya siap siaga menghadapi bencana.

Tantangan yang dihadapi oleh SMP Negeri 2 Cangkringan juga berkaitan dengan kurangnya perhatian instansi terkait dalam hal pembaharuan data secara periodik sesuai karakteristik ancaman, padahal, seharusnya, diperlukan pembaharuan dokumen rencana kontinjensi maupun prosedurprosedur tetap peringatan bahaya secara berkelanjutan. SMP Negeri 2 Cangkringan juga kurang dilibatkan dalam musyawarah forum pengelolaan risiko bencana baik di tingkat desa, kecamatan, 
maupun kabupaten. Kurang adanya pemantauan dan evaluasi secara berkala dan menyeluruh oleh stakeholder juga menjadi tantangan tersendiri, mengingat evaluasi baru dilaksanakan sebatas evaluasi terhadap kegiatan tertentu, bukan evaluasi terhadap keseluruhan program SSB. Kepentingan pengelolaan risiko bencana merupakan hak dan kewajiban seluruh komponen masyarakat, karenanya, menjadi mutlak untuk tetap memperhatikan kepentingan kelompok rentan bencana dalam keadaan ada atau tidak ada tanda bahaya dan ancaman.

Demi mensukseskan program SSB, terdapat beberapa rekomendasi yang dapat dijalankan oleh berbagai komponen, baik sekolah, instansi terkait, maupun masyarakat pada umumnya. Hal tersebut berkaitan dengan penyusunan sistem peringatan bahaya yang tidak dapat dipisahkan dari kegiatan lain, seperti penentuan peta dan jalur evakuasi serta kesiapan tim dalam memahami informasi. Hal tersebut berguna bagi masyarakat terdampak secara langsung. Selain itu, ditentukannya aktivasi rencana kontinjensi sekolah berdasarkan tingkatan aktivitas gunung bukanlah satu-satunya informasi yang dapat langsung diikuti dengan langkah evakuasi. Penentuan langkah evakuasi harus memperhatikan rekomendasi dari pemerintah kabupaten dan desa setempat. Diperlukan adanya keterpaduan rencana kontinjensi yang disusun oleh sekolah dengan rencana kontinjensi kabupaten atau dinas terkait. Hal tersebut bermanfaat demi terciptanya keselarasan tindakan pada saat kondisi darurat bencana. Pemerintah idealnya telah menyusun dokumen rencana kontinjensi yang dapat dijadikan acuan.

\section{DAFTAR PUSTAKA}

Arikunto, S. (2006). Prosedur penelitian, suatu pendekatan praktik. Jakarta: Rhinekka Cipta.

Arikunto, S., \& Jabar, C. S. A. (2014). Evaluasi program pendidikan. Jakarta: Bumi Aksara.

Astuti, S. I., \& Sudaryono. (2010). Peran sekolah dalam pembelajaran mitigasi bencana. Jurnal Dialog Penanggulangan Bencana, 1(1), 30-42.

Badan Nasional Penanggulangan Bencana. (2011). Rencana aksi rehabilitasi dan rekonstruksi pascabencana erupsi Gunung Merapi. Jakarta: Badan Nasional Penanggulangan Bencana.

Cadag, J. R. D., \& Gaillard, J. (2012). Integrating knowledge and actions in disaster risk reduction: The contribution of participatory mapping. AREA Royal Geographical Society, 44(1), 100109. doi:https://doi.org/10.1111/j.1475-4762.2011.01065.x

Desfandi, M. (2014). Urgensi kurikulum pendidikan kebencanaan berbasis kearifan lokal di Indonesia. Sosio Didaktika: Social Science Education Journal, 1(2), 191-198. doi:https://doi.org/10.15408/sd.v1i2.1261

Emzir, E. (2012). Metodologi penelitian pendidikan kuantitatif dan kualitatif. Bandung: Raja Grafindo Persada.

Fauzan, A., \& Djunaidi, G. (2012). Metodologi penelitian kualitatif. Yogyakarta: Ar-Ruzz Media.

Herdiansyah, H. (2011). Metodologi penelitian kualitatif untuk ilmu-ilmu sosial. Jakarta: Salemba Humanika.

Hidayati, D. (2012). Striving to Reduce Disaster Risk: Vulnerable Communities with Low Levels of Preparedness in Indonesia. Journal of Disaster Research, 7(1), 75-82.

Huberman, A. M., Miles, M. B., \& Saldana, J. (2014). Qualitative data analysis: A method sourcebook ( $3^{\text {rd }}$ Edition). USA: Sage Publication.

Kenny, C. (2012). Disaster Risk Reduction in Developing Countries: Cost, Benefits and Institutions. Journal Compilation of Disasters, 36(4), 559-588.

Koswara, A., \& Triyono, T. (2011). Panduan monitoring dan evaluasi Sekolah Siaga Bencana. Jakarta: LIPI Press.

Mulyasa, E. (2002). Manajemen berbasis sekolah: Konsep, strategi, dan implementasi. Bandung: PT Remaja Rosdakarya. 
Pemerintah Daerah Istimewa Yogyakarta. (2010). Peraturan Daerah Provinsi DIY Pasal 51 ayat 2 Nomor 8/2010, tentang Penanggulangan Bencana.

Presiden Republik Indonesia. (1945). Undang-Undang Dasar Republik Indonesia, Tahun 1945, Pasal 3, tentang Hak dan Kewajiban Warga Negara.

Presiden Republik Indonesia. (2007). Undang-Undang Republik Indonesia Nomor 24, Tahun 2007, tentang Penanggulangan Bencana.

Presiden Republik Indonesia. (2008). Peraturan Pemerintah Nomor 21, Tahun 2008, tentang Penanggulangan Bencana.

Selby, D., \& Kagawa, F. (2012). Disaster risk reduction in school curricula: Case studies from thirty countries. Barcelona, Spain: Novoprint SA.

Suarmika, P. E., \& Utama, E. G. (2017). Pendidikan mitigasi bencana di Sekolah Dasar (Sebuah Kajian Analisis Etnopedagogi). Jurnal Pendidikan Dasar Indonesia, 2(2), 18-24. doi:http://dx.doi.org/10.26737/jpdi.v2i2.327

Sugiyono, S. (2012). Metode penelitian pendidikan pendekatan kuantitatif, kualitatif, dan R\&D. Bandung: Alfabeta.

Sugiyono, S. (2015). Metode penelitian dan pengembangan (Suryandari, Ed.). Bandung: Alfabeta.

Suharwoto, G., Amri, A., Pantjastuti, S. R., Praptono, P., \& Wihdiyanto, A. (2015). Modul 3 pilar 3: Pendidikan pencegahan dan pengurangan risiko bencana. Jakarta: Biro Perencanaan dan Kerjasama Luar Negeri Sekretariat Jenderal Kemendikbud.

Suharwoto, G., Amri, A., Pantjastuti, S. R., Praptono, P., \& Wihdiyanto, A. (2015). Roadmap sekolah dan madrasah aman. Jakarta: Kementrian Pendidikan dan Kebudayaan.

Verstappen, H. T. (2010). Indonesian landforms and plate tectonics. Jurnal Geologi Indonesia, 5(3), 197-207.

Verstappen, H. T. (2013). Garis besar geomorfologi indonesia (Suratman, Ed.). Yogyakarta: Gadjah Mada University Press. 